for Earthquake Research, Proposal for a ten-year national earthquakc hazards program: A partnership of science and the community, Office of Science and Technology, Washington, D.C., 1968 .

Press, Frank (Chairman), Ad Hoc Panel on Earthquake Prediction, Earthquake prediction: A proposal for a ten-year program of research, Office of Science and Technology, Washington, D. C., 134 pp., 1965.

Radbruch, D. H., New evidence of historic fault activity in Alameda, Contra Costa, and Santa Clara counties, California, Stanford Univ. Publ. Geol. Sci., 11, 46-54, 1968.

Raleigh, C. B., and R. O. Burford, Tectonics of the San Andreas fault system: Strain studies, EOS, Trans. $A G U, 50,380-381$, 1969.

Raleigh, C. B., J. Bredehoeft, J. H. Healy, and J. Bohn, Earthquakes and waterflooding in the Rangely oil field, Abstracts with Programs, Geol. Soc. Amer. 1970 Ann. Meet., 2, $660-661,1970$.

Rogers, T. H., and R. D. Nason, Active faulting in the Hollister area, in Guidebook to the Gabilan Range and Adjacent San Andreas fault, pp. 102-104, American Association of Petroleum Geologists, Pacific Section, Bakersfield, California, 1967.

Romig, P. R., W. M. Major, D. C. Wideman, and D. Tocher, Residual strains associated with a nuclear explosion, Bull. Seismol. Soc. Amer., 59, 2167-2276, 1969.
Rothé, J. P., Seismes artificiels, Tectonophysics, 9. 215-238, 1970.

Ryall, A., and W.V. Savage, A comparison of seismological effects for the Nevada underground test Boxcar and natural earthquakes in the Nevada region, J. Geophys. Res., 74, 4281-4289, 1969.

Savage, J. C., A theory of creep waves propagating ajong a transform fault, J. Geophys. Res., 76(8), 1971.

Scholz, C. H., and T. V. Fitch, Strain and creep in central California, J. Geophys. Res., 75, 4447-4454, 1970.

Smith, S. W., and M. Wyss, Displacement on the San Andreas fault subsequent to the 1966 Parkfield earthquake, Bull. Seismol. Soc. Amer., 58, 1955-1973, 1968.

Smith, S. W., C. B. Archambeau, and W. Gile, Transient and residual strains from large underground explosions, Bull. Seismol. Soc. Amer., 59, 2185-2196, 1969.

Steinbrugge, K. V., and E. G. Zacher, Creep on the San Andreas fault-fault creep and property damage, Bull. Seismol. Soc. Amer., 50, 389-396, 1960.

Tocher, D., Creep on the San Andreas fault-creep rate and related measurements at Vineyard, California, Bull. Seismol. Soc. Amer., 50, 396-404, 1960.

Toksöz, M. N., D. G. Harkrider, and A. Ben-Menahem, Release of tectonic strain by underground explosions and mechanisms of earthquakes, Bull. Seismol. Soc. Amer., 59, 275--287, 1965.

\title{
Structure
}

\section{and Composition of the Mantle}

\section{Don L. Anderson}

The last four years have been a period of increased emphasis on the problems of discontinuities, lateral variations, and shear velocities in the mantle. The presence of discontinuities near $400 \mathrm{~km}$ and 600 $\mathrm{km}$ has been verified by travel time, apparent velocity, and reflection and amplitude studies; it has been shown by refraction and reflection amplitudes that these discontinuities are extremely sharp, $4 \mathrm{~km}$ or less. Other discontinuities, or abrupt changes in velocity gradient, have been found in the upper and lower mantle. It now appears that there are relatively few large radial stretches of the mantle that are truly homogeneous. A summary of the locations of discontinuities in the mantle is given in Johnson [1967] and Whitcomb and Anderson [1970]. A second-order discontinuity has been found near $500 \mathrm{~km}$ by Helmberger and Wiggins [1971].

Among the new models for the upper mantle are those developed by Johnson [1967], Green and Hales [1968], Archambeau et al. [1969], Julian and Anderson [1968], Helmberger and Wiggins [1971], and Hales et al. [1970]. New models for the lower mantle have been derived by Johnson [1969], Chinnery and Toksöz [1967] and Hales et al. [1968]. Shear-velocity models have been presented by Fairborn [1969], Kovach and

Don L. Anderson is with the Seismological Laboratory, California Institute of Technology, Pasadena 91101.
Robinson [1969], Ibrahim and Nuttli [1967], Anderson and Julian [1969], and Hales and Roberts [1970]. Some of the above studies include amplitudes and $d t / d \Delta$ as well as travel times. Whitcomb and Anderson [1970] used precursors to the core phase $P^{\prime} P^{\prime}$ to study the fine structure of the upper mantle under the Indian and Atlantic Oceans.

Hales et al. [1970] found a refractor under the Gulf of Mexico at a depth of $57 \mathrm{~km}$ that had a velocity of $8.77 \mathrm{~km} / \mathrm{sec}$. A similar velocity had previously been found at $90 \mathrm{~km}$ under the central United States and under the Aleutian arc, indicating that such velocity may be a common feature of the upper mantle in regions where it is not masked or obliterated by the low-velocity zone. Helmberger and Wiggins [1971] have velocities of 8.7 to $8.9 \mathrm{~km} / \mathrm{sec}$ between 200 and $400 \mathrm{~km}$, which is consistent with a generally faster upper mantle than previously supposed.

Progress in the composition of the mantle requires laboratory as well as seismic data. The main inputs are from ultrasonic and shock wave measurements. The articles by Sammis, by Liebermann and Schreiber, and by Ahrens and Takahashi in this series summarize progress in these areas.

Ultrasonic measurements are now available for olivine, pyroxene, garnet, and spinel. These are the most abundant minerals of the upper mantle, and their densities and seismic velocities are consistent with properties of the upper mantle, except in the vicinity of the low-velocity zone. The most satisfactory explanation of the upper mantle low-velocity zone involves partial melting.

Shock wave data are now being routinely used to interpret the composition of the lower mantle. Several studies have indicated that the lower mantle is enriched in $\mathrm{FeO}$ relative to the upper mantle; it 
may also be enriched in $\mathrm{SiO}_{2}$, i.e., it be more pyroxene rich than the upper mantle. These conclusions are based primarily on shock wave data for two dunites and stishovite and on new lower mantle density distributions based on the inversion of free oscillation data. Shock wave data on pyroxenes are required in order to make further progress.

Anderson [1970], Wang [1970], Graham [1971], Birch [1970], Press [1970], Anderson and Jordan [1970], and Anderson et al. [1970] discuss the composition of various regions of the mantle.

\section{Acknowledgment}

This paper is Contribution 1963 of the Division of Geological and Planetary Sciences, California Institute of Technology, Pasadena.

\section{REFERENCES}

Anderson, Don L., Phase changes in the upper mantle, Science, 157(3793), 1165-1173, 1967.

Anderson, Don L., Chemical inhomogeneity of the mantle, Earth Planet. Sci. Lett. 5, 89-94, 1968.

Anderson, Don L., Petrology of the Mantle, Mineral. Soc. Amer. Spec. Pap., 3, 85-93, 1970.

Anderson, Don L., and Thomas Jordan, The composition of the lower mantle, Phys. Earth Planet. Interiors, 3, 23-35, 1970.

Anderson, Don L., and Bruce R. Julian, Shear velocities and elastic parameters of the mantle, J. Geophys. Res., 74, 3281, 1969.

Anderson, Don L., and Charles Sammis, the low velocity zone, Geofis. Int., 9, 1-3, 3-19, 1969.

Anderson, Don L., and Charles Sammis, Partial melting in the upper mantle, Phys. Earth Planet. Interiors, 3, 41-50, 1970.

Anderson, Don L., Charles Sammis, and Thomas Jordan, Composition of the Mantle and Core, Science, in press, 1971.

Archambeau, C. B., E. A. Flinn, and D. G. Lambert, Fine structure of the upper mantle, J. Geophys. Res., 74, $5825-5865,1969$.

Birch, F., Interpretations of the low-velocity zone, Phys. Earth Planet. Interiors, 3, 178-181, 1970.

Chinnery, M., and M. N. Toksöz, P-wave velocities in the mantle below $700 \mathrm{~km}$, Bull. Seismol. Soc. Amer., 57, 199, 1967.

Derr, J. S., Internal structure of the earth inferred from free oscillations, J. Geophys. Res., 74, 5202, 1969.

Fairborn, J., Shear velocities in the lower mantle, Bull. Seismol. Soc. Amer. 59, 1983, 1969.

Graham, Earl K., Jr., Elasticity and composition of the upper mantle, Geophys. J. Roy. Astron. Soc., 20, 285-302, 1970.

Green, R. W. E., and A. L. Hales, The travel times of $P$ waves to $30^{\circ}$ in the central United States and upper mantle structure, Bull. Seismol. Soc. Amer. 58, 267, 1968.

Hales, A. L., A seismic discontinuity in the lithosphere, Earth Planet. Sci. Lett., 7, 44-46, 1969.

Hales, A., and J. Roberts, Shear velocities in the lower mantle and the radius of the core, Bull. Seismol. Soc. Amer. 60, 1427, 1970.

Hales, A., J. Cleary, and J. Roberts, Velocity distribution in the lower mantle, Bull. Seismol. Soc. Amer., 58, 1975, 1968.

Hales, A. L., C. E. Helsley, and J. B. Nation, $P$ travel times for an oceanic path, $J$. Geophys. Res., 75, 7362-7381, 1970.

Helmberger, D., and R. A. Wiggins, Upper mantle structure of midwestern United States, submitted for publication in J. Geophys. Res., 1971.

Ibrahim, A. K., and O. W. Nuttli, Travel-time curves and upper-mantle structure from long-period $S$ waves, Bull. Seismol. Soc. Amer., 57, 1063, 1967.

Johnson, Lane, Array measurements of $P$ velocities in the upper mantle, J. Geophys. Res., 72, 6309-6325, 1967.

Johnson, Lane, Array measurements of $P$ velocities in the lower mantle, Bull. Seismol. Soc. Amer., 59, 973-1008, 1969.

Julian, B. R., and D. L. Anderson, Travel times, apparent velocities and amplitude of body waves, Bull. Seismol. Soc. Amer., 58, 339, 1968.

Kovach, R., and R. Robinson, Upper mantle structure in the Basin and Range province, western North America, from the apparent velocities of $S$ waves, Bull. Seismol. Soc. Amer., 59 $1653,1969$.

Press, F., The suboceanic mantle, Science, 165, 174-176, 1969.

Press, F., Earth models consistent with geophysical data, Phys. Earth Planet. Interiors, 3, 3-22, 1970.

Wang, C. Y., Density and constitution of the mantle, $J$. Geophys. Res., 75, 3264-3284, 1970.

Whitcomb, James H., and Don L. Anderson, Reflection of $P^{\prime} P^{\prime}$ seismic waves from discontinuities in the mantle, $J$. Geophys. Res., 75, 5713-5728, 1970.

\section{Structure, Composition, and State of the Core}

\author{
Bruce A. Bolt
}

\section{Main Developments}

Since 1967 two major advances in our knowledge of the core and core-mantle boundary have occurred. First, the giant large-amplitude seismic array (Lasa) in Montana provided convincing observations of reflections

Bruce A. Bolt is with the Seismographic Station, Department of Geology and Geophysics, University of California, Berkeley 94720 .
$(P K i K P)$ from the inner-core boundary (ICB); second, evidence grew that a low-velocity shell existed in $P$ and $S$ above the mantle-core boundary (MCB).

After the recent energetic studies of the upper mantle, there are signs of quickening geophysical interest in the physical state of the earth's core. The precise nature of the striking structural discontinuities that define the MCB and ICB is of importance to solid-state physics, to geochemistry, and to geophysics. In particular, laboratory shock-wave results must be matched against the seismological inferences.

Observatory instrumentation, especially the high-gain array facilities, has become more sensitive and suitable for probing the fine structure of the core. Previously recondite core phases like $P K K K K K P$ are now regularly observed [Engdahl, 1968b].

Progress on relevant seismic wave theory has mainly 